\title{
The Effect of Shared Knowledge on the Productivity Aspect of Performance of the Manufacturing Firms in Nigeria
}

\author{
Solomon Adejare Babarinde $(\mathrm{PhD}) * \quad$ Adeyemi Omolade \\ Department of Business Administration, Oduduwa University, P.M.B 5533, Ile-Ife, Osun State, Nigeria
}

\begin{abstract}
This study examines effect of shared knowledge on the productivity aspect of performance of the manufacturing firms in Nigeria. The research design chosen in the study is a combination of a survey and oral interview. A representative sample of 504 respondents was chosen using the table of random numbers from a population of 735 respondents from Nigerian Breweries Plc., Guinness Nig. Plc. and Bendel Breweries Plc. The data presentation tools were tables. The data analyses tools were percentages $\mathrm{Z}$ test, and $\mathrm{Z}$ test of population proportions. The $\mathrm{Z}$ test and $\mathrm{Z}$ test of population proportions was used to test the hypothesis. The test-retest method of reliability and content validity were used. The result of the study found that there is a positive effect of shared knowledge on the productivity aspect of performance of the manufacturing companies $(Z$ value $=3.429>Z$ critical value $=1.645)$. The results indicate that shared knowledge practices are positively associated with organizational performance in the manufacturing companies. It was concluded that as shared knowledge increased, the performance of the firms also increased. It is therefore recommended that strategic managers of the manufacturing firms studied should as a matter of policy continue to use shared knowledge as a tool for improving productivity aspect of performance in their companies.
\end{abstract}

Keywords: Knowledge, shared knowledge, performance, knowledge utilization, firms

DOI: $10.7176 / \mathrm{EJBM} / 11-9-06$

Publication date:March $31^{\text {st }} 2019$

\section{INTRODUCTION}

Over the years, the nature of competition has changed to the extent that company no longer compete against other companies on the bases of quality as traditionally practiced in the 80s (Mensah et., 2014; Fawcett et al., 2007). In addition, rapid technological developments have contributed to uncertainty and unpredictability in all sectors that have emphasized the importance of the ability of an organization to adapt to unexpected changes, something that is considered to be critical to achieving and maintaining a competitive advantage (Kanaan and Masa'deh, 2013). Indeed, knowledge management came in this sequence to enhance organizational effectiveness and competitiveness. Knowledge management (KM) is a formal process of determining what information an organization has that can benefit employees in the organization and making the information easily available for use by those who need it (Carlson, 1999 cited in Peariasamy and Mansor, 2008). Effective knowledge management is essential to provides "the capacity to engineer an organization's formal and informal structure, function and processes to formalize and leverage its intellectual assets" (Fong and Kwok, 2009).

One of the goals of many knowledge management projects is to encourage the sharing of knowledge among employees. Knowledge sharing is a key component of knowledge management systems (Alavi \& Leidner, 2001; Earl, 2001). Kumar and Rose (2012) report that knowledge management alone cannot lead organization to success; it should also consider knowledge sharing and its various enablers working together. So knowledge sharing is most important processes of knowledge management, which slowly develop and pick up the building block of the system. Shared knowledge as a concept according to Kim and Lee (2006) refers to dissemination of individual employees' work-related experiences and collaboration between and among individuals, subsystems in the organization. It refers to the given and receiving of information framed within a context by the knowledge of the source and recipient. Knowledge given by the source and received by a recipient cannot be identical as the process of interpretation is subjective and is framed by existing knowledge and identity (Miller, 2002 in Sharratt and Usoro, 2003). Kim and Lee (2006) echo the view of Dyer (1997) and Inkpen and Beamish (1997) that knowledge sharing requires the dissemination of individual employees' work-related experiences and collaboration between and among individuals, subsystems in the organization. The basic reason of knowledge sharing is to make easy knowledge shift from one person to another person, to take in the knowledge from outside and then adopt it (Akram and Bokhari, 2011).

Shared knowledge promote innovative product and services develop with higher quality, without any duplication, and customer's service quality etc (Krogh, 1998). Shared knowledge is a key function of knowledge management initiatives that leverage knowledge for the benefit of an intended audience. The overall aim of shared knowledge is to help organizations to outperform direct competitors. Ohiorenoya and Eboreime (2014) in their study revealed that knowledge sharing practices is a veritable tool for the improvement of services and process and for growth and productivity. Inkpen (2000) asserts that unless individual knowledge is shared throughout an organization, the knowledge will have a limited impact on organizational effect. This support Lin's (2008) 
assertion that: "the exchange of knowledge and sharing of experiences among different organizational units." The two implications of knowledge sharing discussed by Almahamid, McAdams and Kalaldeh (2010) are individual learning commitments and individual adaptability. These are expected to improve individual competencies and then lead to individual job satisfaction.

Shared knowledge as it were is divided into two major strategies and these are codification and personalization. Codification approach refers to formalization of tacit knowledge.

Tacit knowledge is knowledge that has not been made explicit and cannot be precisely articulated (Rashman and Hartley, 2002; Brooking, 1999). This is the knowledge people have in their minds. It is unspoken understanding about something; quite difficult to write down (Nonaka, 1991 in Con and Pandya, 2003). Personalisation on the other hand refers to approach based on technologies, such as intranets, repositories, databases, etc. This strategy emphasizes knowledge sharing among individuals, groups, and organizations through social networking and/or engaging in 'communities of prcatice' (Hansen, Nohira and Tierney; Khakpour, Ghahremani and Pardakhtchi, 2009). Both codification and personalization strategies are appropriate for sharing explicit and tacit knowledge in organizations.

There have been various studies on knowledge management in developing countries. But these studies have rarely point out the relationship between shared knowledge and organizational performance which creates problem for the researchers to build and the quantitative theory of knowledge sharing towards performance (R. Du et al, 2007) and has made it more difficult towards knowledge sharing and its effect on industrial organization performance. It is also argue that sharing of knowledge by an individual to another person in an organization will make the source to lose his power to the receiver (Shiah-Hou, and Joseph Yu, 2006). On the contrary, other researchers have disagreed that sharing of knowledge leads to the elimination of individual power; rather it makes individual or source to be prominent in an organization (Tannenbaum, 1968). Shared knowledge also improves organization performance (Shiah-Hou and Joseph Yu, 2006). This paper examines the effect of shared knowledge on the productivity aspect of performance of manufacturing companies in Nigeria. In view of this objective, it is hypothesizes that shared knowledge has no significant effect on productive aspect of performance of manufacturing companies in Nigeria.

This paper focuses on manufacturing sector in Nigeria which has been noted to demonstrate weakness in its contribution to national economy (Akinniyi, 2013). This weakness is evident in less than $10 \%$ contribution to manufacturing to the gross domestic product (GDP); very low value of manufactured export which is less than $1 \%$ of total export; and low level of employment in the industry, among others. Manufacturing sector in Nigeria has wrong investment decision-making, and inability to adapt foreign technology to suit local needs for sustainable development (Ajakaiye \& Akinbinu, 2000). Therefore, considering the importance of the manufacturing sector, it is appropriate to investigate how shared knowledge is practiced and the influence it wields on the performance of manufacturing industry.

\section{Statement of the Problem}

The extant studies on the implementation of knowledge management practices for improved productivity, innovation, and competitive advantage have focused on organizations of developed economies like USA, Europe and Asia. However, there have been limited researches about the implementation of shared knowledge in the manufacturing sector of the economy in Nigeria. A problem arises as to whether the findings of those studies can be replicated in developing countries like Nigeria. The inability to determine the impact of shared knowledge on performance leads to a difficulty for managers of manufacturing firms studied. Additionally, there is a difficulty in determining the effect of shared knowledge on the performance of the manufacturing firms studied. This difficulty has led to the obstacle of the difficulty in finding out whether the contribution of shared knowledge to the performance of the manufacturing firms studied compared favourably with international standard. This study sets to fill the gap by establishing whether shared knowledge has an effect on the productivity aspect of performance of the manufacturing firms in Nigeria.

\section{Objectives of the study}

The general objective of this study is to analyze determine the extent of the effect of shared knowledge on the productivity aspect of performance of the manufacturing firms in Nigeria. Specifically, this paper is to empirically determine whether shared knowledge has enhance the productivity aspect of performance of the selected manufacturing firms in Nigeria or otherwise.

\section{LITERATURE REVIEW}

\subsubsection{The concept of Knowledge}

Knowledge is defined as what people understand about things, concept, ideas, theories, procedures, practices and the way we do things here. It can be described as 'know - how' or, when it is specific, expertise (Armstrong 2009)

- A distinction was made by Ryle (1994) between 'knowing how' and 'knowing that', knowing how is the 
ability of a person to perform tasks, and knowing that is holding pieces of knowledge

- In one's mind, Blackler (1995) noted that knowledge is multifaceted and complex, being both situated and abstract, implicit and explicit, distributed and individual physical and mental developing and static, verbal and encoded.

- Nonaka (1991) suggested that knowledge is held either by individual or collectively.

- Blackler's (1995) terms, embodies or embraced knowledge is individual and embedded, and cultural knowledge is collective. It can be

- $\quad$ Argued (scarborough and carter, 2000) that knowledge emerges from the collective experience of eork and is shared between members of a particular groups or community.

\subsubsection{Explicit and Tacit knowledge}

* Nonaka (1991) and Takeuchi (1995) state that knowledge is either explicit or tacit. Explicit knowledge can be codified- it is recorded and available and is held in databases, In corporate intranets and intellectual property portfolios. Tacit knowledge exists in people mind. It is difficult to articulate in writing and is acquired through personal experience. As suggested by

* Hansen et al (1999), it includes scientifics or technological expertice, operational know-how, insights about an industry and business judgement. The main challenge in knowledge management is how to turn tacit knowledge into explicit knowledge.

\subsubsection{Data, information and knowledge}

A distinction can be made between data, information and knowledge according to (Armstrong 2009).

Data consists of the basic facts- the building blocks- for information and knowledge.

Information is data that have been processed in a way that is meaningful to indidual; it is available to anyone entitled to gain access to it.

- $\quad$ As Drucker (1988) wrote, information is data endowed with meaning and purpose;

- Knowledge is information put to productive use; it is personal and aften intangible and it can be exclusivethe task of trying it down, encoding it and distributing it is tricky.

\subsubsection{The Concept of Shared Knowledge}

Different authors have described knowledge differently (Akram and Bokhari, 2011).

According to Davenport and Prusak (1998) as cited in Akram and Bokhari (2011), knowledge is as an evolving mix of framed experience, values, contextual information, and expert insight that provides a framework for evaluating and incorporating new experiences and information. It is an understanding gained in human mind following a processing or reflection on contextual information available to it (Brooking, 1999). Knowledge can therefore be said to one's perception or understanding gained on a particular subject matter following an interpretation of information, experiences and lessons learnt from life or environmental realities. Nonaka and Takeuchi (1995) in Kim and Lee (2006) identify three characteristics of knowledge as follows: knowledge is a function of a particular perspective, intention, or stance taken by an individual; knowledge is always about some end, which means that knowledge is about action; and knowledge is context specific and relational, and therefore it is about meaning. From this description, knowledge can be seen as insight or understanding gained or created in human's mind from information available to it.

Knowledge utilization is "the productive deployment of organizational knowledge in the production process" (Probst, 1998). It is also the adoption or adaptation of knowledge shared with the recipient (Roy, Parent and Desmarals, 2003). Knowledge utilization is further said to occur when learning is integrated into the organization (Tiwana, 2000). This author considers knowledge utilization as simply the application of knowledge possessed by individuals or organizations to get desired results.

Shared knowledge is that aspect of knowledge that is available to a lot of people in the group. Knowledge sharing refers to the provision of task information and know-how to help others and to collaborate with others to solve problems, develop new ideas, or implement policies or procedures (Cummings, 2004; Pulakos, Dorsey, and Borman, 2003). Knowledge sharing can occur via written correspondence or face-to-face communications through networking with other experts, or documenting, organizing and capturing knowledge for others (Cummings, 2004; Pulakos et al., 2003). It can be considered as the exchange of knowledge between two or more individual or parties; including institutions (Dyer, 1997; and Inkpen and Beamish, 1997 in Kim Lee, 2006). Although the term knowledge sharing is generally used more often than information sharing, researchers tend to use the term "information sharing" to refer to sharing with others that occurs in experimental studies in which participants are given lists of information, manuals, or programs.

Knowledge sharing differs from knowledge transfer and knowledge exchange. Knowledge transfer involves both the sharing of knowledge by the knowledge source and the acquisition and application of knowledge by the recipient. "Knowledge transfer" typically has been used to describe the movement of knowledge between different units, divisions, or organizations rather than individuals (Szulanski, Cappetta, and Jensen, 2004). Although "knowledge exchange" has been used interchangeably with "knowledge sharing" (Cabrera, Collins, and Salgado, 
2006), knowledge exchange includes both knowledge sharing (and employees providing knowledge to others) and knowledge seeking (or employees searching for knowledge from others). In this review, we use the term "knowledge exchange" when discussing studies that measured knowledge sharing using scales that assessed both knowledge sharing and seeking.

Knowledge sharing is a critical process for managing knowledge in the work place because it tends to support the acquisition of competence generally and particularly managerial competence for improved productivity. Smith and Mckeen (2002) propose social context, organizational context, organizational context, managerial context and technical context as enabling factors that reinforce the process of sharing knowledge which the authors see as having a link to the acquisition of managerial competence.

Knowledge sharing and knowledge utilization are inseparable factors that have the potential to foster effectiveness in organizations. When knowledge shared with individuals and teams within an organization is applied, there is a high probability that the competence will be enhanced. This same principle should apply to the acquisition of managerial competence.

Managerial knowledge, skills and attitude shared and utilized by an organization's workforce should logically lead to improved level of managerial competence necessary for meeting its corporate objectives. Nissen (2007) in Oye, Salleh and Noorminshah (2011), observed that the emergence of the knowledge-based economy...and the intensification of competition have come together to require organizations to be as agile and intelligent as they can be, and one important way for organizations to meet this requirement is to enable organizational members to share their knowledge efficiently.

Kremp and Mairesse (2003) have found that knowledge measurement have positive effects on Labour Productivity. It is acknowledged that management processes have significant effects on knowledge management success and that IT impact on knowledge management success is not direct but mediated through knowledge management process. Leadership, culture and strategy influence knowledge management infrastructure. Keramti and Axadeh (2007) believe that factors responsible for commitment knowledge management success are knowledge sharing, knowledge creation and knowledge transfer. It is argued that the ability of the firm to create knowledge helps to explain the firm's ability to innovate and grow. Strategic alliance leads to better firm performance.

Market research and use of networks for knowledge exchange are linked to higher sales turnover growth. Cooperation with other firms for renewal is found to be positively related among medium scale firms. However, output strategies such as sharing, codification of knowledge, firm-provided training and quality certificates have no positive effects just in the same manner output strategies: patents, new products or services and improvement of internal processes do not have positive effects on performance. Knowledge management input strategies are found to be clearly better predictors of sales turnover. Research evidence suggests that innovation is positively related to rapid sales growth within small firms (Storey, 2000) and that there is a significant positive relationship between marketing research and development and sales growth. A positive relationship also exists between new product introduction and re-designed products and total sales growth. Non innovators are more prevalent in declining, stable and low (to average) growth firms while innovators exceed noninnovators in the supper-growth category (Uhlaner, 2007). To be able to define and measure progress toward the achievement of the goals of organization, every organization must be abreast with its key performance indicators and crucial success factors.

Wu and Wang (2006) find in their study that system quality and knowledge or information quality have a significantly positive influence on user satisfaction. Also, user satisfaction and perceived knowledge management system benefits have a direct effect on knowledge management system use. In the knowledge management system context, they find that user attitude is affected by beliefs about system quality and knowledge or information quality, which then affect knowledge management system use. Users' beliefs about the knowledge management system quality shape their attitude and this affects their knowledge management system use. They further find that system quality, knowledge or information quality, and perceived benefits have a significantly positive influence on user satisfaction because they want their knowledge management system to be of high system quality, high knowledge or information quality, and provide substantial benefits. However they do not find the system quality of the knowledge management system to have a significantly direct influence on user perceived benefits. Firms that adopt knowledge management system significantly reduce administrative costs and improve productivity in the second year after adopting knowledge management system and gaining a competitive advantage over nonadopters (Kuoching, 2004).

2.1.2 Concept of the Performance of the Manufacturing Firms Performance in business setting means the extent to which an objective has been or is being met. Put in another way, performance refers to the degree to which organizational goals are achieved. The performance of manufacturing firms is in the context of the extent to which they achieve their goals and objectives. Manufacturing firms have a lot of performance factors and the performance factors include:

- Efficiency.

- Effectiveness. 
- Productivity.

- Profitability.

- Solvency.

Efficiency refers to the rate of resource utilization, i.e. cost incurred in the course of work done. It is also defined as fitness or power to accomplish, or success in accomplishing the purpose intended, adequate power, effectiveness, efficacy, etc. Effectiveness refers to the extent to which results are achieved by ways of units of goods produced or sold, value of content executed, etc. Effectiveness implies to have effects, when something is said to be effective, it means that it has effects that are desired and recognized as intentional in the design of the thing in question. Productivity is defined as the measure of how well resources are brought together in organizations and utilized for accomplishing a set of results. Profitability is the ability of an enterprise to make profit. Profit is the income or difference between sales revenue and total cost. Solvency is the ability of an enterprise to meet its immediate obligations and thus avoid the possibility of insolvency (Nwachukwu, 2008).

In evaluating and assessing performance of a business enterprise, attempt is made to examine not only the resultant outcome of the company's efforts in terms of returns (profit and its other derivation), but also those aspects of the company's financing and asset structure which indicate its ability to survive or its disposition to avail itself of future opportunities. In practical parlance, performance is looked at in the context of the delivery to the promise made to stakeholders. This is why many oil producing firm in the Niger Delta in Nigeria have problems with their host communities because they continue to fail to make good their promises even when there is full degradation of soil during their operations. The major areas of performance customarily evaluated are profitability, liquidity, leverage (long term solvency) and activity or efficiency of operation (Nwachukwu, 2008).

Key Performance Indicators (KPIs) or key success indicators (KSIs) are quantifiable performance measurements used to define success factors and measure progress toward the achievement of business goals. Organizations that have well defined goals, well analysed mission and have identified their stakeholders need to measure progress toward the achievement of those goals by using key performance indicators. KPLs are quantifiable measures that reflect the critical success factors of an organization (Reh, 2010).

\subsubsection{Knowledge Management and Manufacturing firms}

Knowledge Management is any process or practice of creating, acquiring, capturing, sharing and using and knowledge, where it resides, to enhance learning and performance in organisations (scarborough et al, 1999). They suggest that it focuses on the development of firm-specific knowledge and skills that are the result of organisational learning processes. Knowledge management connotes basically entails both stocks and flows of knowledge. Stocks involved expertise and encoded knowledge in computer systems. Flows represent the ways in which knowledge is transferred from people to people or from people to a knowledge management has also been defined by $\tan (200)$ as:

The process of systematically and a actively managing and leveraging the stores of management in an organization. knowledge according to Armstrong (2009), involve transforming knowledge resources by identifying relevant information knowledge and them disseminating it so that learning can place. Knowlegde management strategies promote the sharing of knowledge by linking people with people and by linking them to information so that they learn from documented experiences. Knowledge management is therefore about achieving organization goals through strategy- driven motivation and facilitation of workers' knowledge to develop, enhance and use their capability to interpret data and information (by using available sources of information, experience, skills, culture, characters, personality, feelings etc)through a process meaning to those data and information.

(Beijerse 1999. Consequently, knowledge management acts as a keys approach to solve organisation problems such as competitiveness and the need to innovate. Sustainable competitive advantage is dependent on building and exploiting core competencies.

The relevance of an appropriate management of corporate knowledge is rapidly increasing in modern manufacturing (Fischer and Stokic, n.d.) The business environment where manufacturing industries operate continues to change due to globalization, advancement in technology, changes in managerial practices and other social factors. Consequently, manufacturing functions confront with new challenges in terms of market diversity, changing customer requirements, shorter product lifecycles, rapid market and technological changes, and the spread of advanced manufacturing technologies (Mohammed, 2006).

In the face of increasing competition and compliance requirements, manufacturers need to improve business processes in order to increase operational efficiencies; meet customer demands and manage products globally. Knowledge management offers manufacturers the opportunity to systematically and actively manage and leverage the stores of knowledge in their organizations for a competitive advantage (Sethi, 2009) and to achieve other set goals.

\subsection{Theoretical Framework}

This study is anchorage on the Solow-Swan theory which shows growth as increased capital stock and endogenous theory which holds that subsidies on research and development or education increase the growth rate by increasing 
the incentive to innovation and Solow-Swan models believes that new capital is more valuable than old capital because since capital is produced based on known technology, and technology improves with time, new capital will be more productive than old capital. The implication of this model to knowledge management is that application of knowledge will lead to creating new capital which will be more productive than old capital and thus lead to growth. Growth may be organic or inorganic. Organic growth means that the organization itself has grown from its own business activity while inorganic growth means that the company has grown by merger or acquisition. Organic growth is internal growth and inorganic growth is external. Companies want to grow in order to gain economies of scale and, spread risk (diversification can help to spread risk and increase profits and therefore returns for shareholders).

\subsection{Empirical Studies}

Krempt and Mairease worked on the effect of the shared knowledge on the performance of some manufacturing firms. They found that shared knowledge had a positive effect on labour productivity aspect of performance. They did a survey using a sample of 120 staff of the manufacturing firms. Keramti and Aradesh worked on the factors responsible for commitment knowledge management success. They did a theoretical review as their research design combined with content analysis. They found that the commitment knowledge factors were knowledge sharing, knowledge creation, and knowledge transfer.

Kuo and $\mathrm{Wu}$ (2007) did a study to find out if the contribution of shared knowledge to the performance of manufacturing firms compared well with international standard. They did a survey using a sample of 200 workers in manufacturing firms in Los Angeles, United States of America. They found that there was a positive contribution of shared knowledge on the performance of the firms that compared well with international standards.

Rochart (1979) has done a study to find out the effect of knowledge sharing capacity of workers on the sustainable competitive performance of the manufacturing firms. He did a survey using a sample of 180 workers in manufacturing firms in Ohio in the United States of America. He found that the knowledge sharing capacity to a large extent improved the performance of the manufacturing firms.

Goffee and Jones (2000) did a study on the extent to which tacit knowledge helps to improve the performance of the manufacturing firms. They did a survey of 150 workers of the manufacturing firms in Buffalo, United States of America. They found that tacit knowledge to a large extent improved the performance of the manufacturing firms.

Hasnsen et al (1999) did a study to find out the principal modes of explicit knowledge that contribute to a sustained performance of the manufacturing firms. They did a survey of a sample of 250 workers in manufacturing firms in Philadelphia, United States of America. They found that combination and externalization were the principal modes of explicit knowledge that contributed to a sustained performance of manufacturing firms.

Goffer and Phrahalad (1990) did a study to find out the extent to which knowledge based capacity is considered the most strategic resource for improving the profitability of the manufacturing firm. They did a survey of 300 workers in manufacturing firms in Texas, United States of America. They found that to a large extent, knowledge based capacity was considered one of the resources but not the most strategic resource for improving the profitability of the manufacturing firms.

\section{METHODOLOGY}

The design for this study was survey research design of the descriptive type. A survey is a planned collection of data over a large area for the purpose of analyzing the relationships between variables (Ajike, Akinlabi, Magaji and Sonubi, 2015; Oppenheim, 1992). The independent variable of the study was shared knowledge, while the dependent was organizational performance. The population of study consisted of staff in Nigeria Breweries Plc, Guinness Nigeria Plc and Bendel Breweries Plc. The information collected from the Human Resource Department of the manufacturing companies showed that Nigeria Breweries Plc had three hundred and two (302) staff, Guinness Nigeria Plc had three hundred and nine (309) staff and Bendel Breweries Plc had one hundred and twenty four (124) staff. Therefore, the total population of this study is 735.

A sample size of 504 respondents was selected for the study using Yaro Yamane's standard formula for sample size determination. The sample was drawn from all the departments in the companies and it also encompassed the senior staff in order to ensure adequate representation of view and generalizations.

The instrument used was structured questionnaire tagged "Shared knowledge and Organizational Performance Questionnaire" (SHOPQ). The questionnaire consisted of two sections (A \& B); Part A consisted of questions necessary to generate adequate personal information about the respondents, while Part B consist questions necessary to generate useful data for the study, i.e. it focused on the essential principles or effects of shared knowledge on performance of the manufacturing firms in Nigeria addressing the research questions. Using a Likert scale of 1-5 where 5 is strongly agree and 1 strongly disagree, scores were given for each question by the respondents. The interview method also contributed immensely to the study. It was used to supplement the questionnaire in order to obtain vital information that could not be got through questionnaire. Through personal 
interview, such information as the firm's manpower size, its historical background, its policy on shared knowledge and performance. In order to ensure the validity and reliability of the instrument, 100 copies of the questionnaire were pre-tested among staff of Life Breweries Plc and Brewtech Nigeria Limited at the their Headquarters located in Tony Oghenejode Close, Off Omitire Johnson Street, Phase 1, Lekki, Lagos and 1, Brewtech Street, Ojota, Lagos respectively. However, they did not form part of the total respondents used for this study. The test re-test method using Spearman's Rank correlation coefficient was used to determine reliability co-efficient of the instrument and the value of 0.97 was obtained for shared knowledge scale and 0.87 for organizational performance scale. The validity of the measuring instrument was established through the combination of face and content validity by the researcher.

The administration of the questionnaire was done personally by the researcher. Out of the 504 copies of the questionnaire distributed to respondents, 500 questionnaires were retrieved representing $99.2 \%$ return rate. Statistics such frequency count and percentages were put to use in the analysis of research questions while research hypothesis was tested using Z-test statistic. The research hypothesis was tested at 0.05 level of significance. Analysis was carried out with the aid of Statistical Package for Social Sciences (SPSS).

\section{DATA ANALYSIS AND INTERPRETATION}

\subsection{Demographic Profile of the Respondents}

The demographic profile of respondents reveals that $68.2 \%$ of the respondents were male while a sizeable percentage of $31.8 \%$ were female. Majority $(88.6 \%)$ of the respondents were within 45 years and below age range while only $11.4 \%$ were above 56 years, which could mean that majority of the respondents in the sampled companies are in their middle ages and this age usually constitute the vibrant cream of the workforce in the industrial setting.

With regard to marital status, majority $(68.2 \%)$ of the respondents are married, followed by respondents who are single (29.2\%) and widowed (5 or $1 \%$ ) while other options made available in the question attracted $1.2 \%$. The educational qualification of the respondents revealed that majority of them possessed Senior School Certificate Examination (184 or $36.8 \%$ ) and this was followed by those who possessed First Degree (87 or $17.4 \%$ ). The number of respondents with HND certificate amounted to $12.2 \%, 7 \%$ had ordinary national diploma while $14.8 \%$ of the respondents had below ordinary national diploma certificate. About $5.4 \%$ and $0.4 \%$ of the respondents had Masters Degree and PhD certificates respectively. This interpretation confirms that some levels of skills are required to work in manufacturing industry.

The distribution of respondents by working experience showed that $34 \%$ of the respondents have put in between 11-15 years of experience while $22.2 \%$ of the respondents have worked for 5-10 years. This was followed by $15.2 \%$ of the respondents who have been on the job for $16-20$ years and $14.8 \%$ of the respondents have worked for 1-5 years. This implies that majority of the respondents have spent a good number of years in their companies and would provide appropriate answers to the research questions. In respect of present status of the respondents, majority of the respondents (350 or $70 \%$ ) were senior staff, while junior staff accounted for $30 \%$ of the total respondents.

\subsection{Testing of Hypothesis}

This section involves the test of the research hypothesis using the $\mathrm{z}$ test of population proportions. The hypothesis was tested individually between the variables. The data for shared knowledge and productivity aspect of performance of the manufacturing firms were created by summing the items for each of the dimensions to create new variable. The results of the sample mean, sample standard deviation and calculated $\mathrm{z}$ values are presented in Tables 4.1

Table 4.1: Summary of Z-Score Results of effect of shared knowledge on the productivity aspect of performance of the manufacturing firms

\begin{tabular}{|l|l|l|l|l|l|}
\hline Number & $\begin{array}{l}\text { Number of respondents } \\
\text { that agreed or strongly } \\
\text { agreed }\end{array}$ & Sample size & $\begin{array}{l}\text { Calculated z } \\
\text { value }\end{array}$ & Table z value & $\begin{array}{l}\text { Statistical } \\
\text { decision }\end{array}$ \\
\hline 1 & 473 & 500 & 3.429 & 1.645 & Reject Ho \\
\hline
\end{tabular}

Source: Field survey, 2018

From table 4.1, the $Z$ value (3.429) is greater than $Z$ critical value (1.645) with a p-value of 0.03; probability of rejecting a correct null hypothesis is less than 0.05 hence the alternative hypothesis is adopted and the conclusion that there is a positive effect of shared knowledge on the productivity aspect of performance of the manufacturing firms. The finding is supported by Gold et al (2001) who found a strong and significant relationship between both knowledge infrastructure and knowledge processing with organizational effectiveness, measured by using a broad set of non-financial outcomes (e.g. innovation, coordination, responsiveness, ability to identify market opportunities, speed to market, and process efficiency). Okunoye and Karsten (2002) state that knowledge has become the underlining source of competitive advantage for successful organizations regardless of size and 
geographical locations. Furthermore, the study of Mohrman et al (2003) reported that the extent to which the organizations created and exploited knowledge contributes to the relationship with the overall performance, including financial metrics. Similarly, Zack et al (2009) investigated the relationships among knowledge management practices, intermediate and financial outcomes and the organization's competitive environment. The results indicate that shared knowledge practices are positively associated with organizational performance.

Noe (2005) has observed that shared knowledge had a positive effect on the performance of organizations. This he stated was because shared knowledge was got through learning theories. Learning has been a relatively permanent change on human capabilities and not necessarily a result of growth processes. These capabilities are related to specific learning outcomes. A notable learning out is the improvement in the performance of the learner which in turn leads to the improvement in organizational performance (Noe, 2005). Kremp and Mairesse (2003) have found that knowledge measurement have positive effects on Labour Productivity. Firms that adopt knowledge management system significantly reduce administrative costs and improve productivity in the second year after adopting knowledge management system and gaining a competitive advantage over non-adopters (Kuoching, 2004). The finding of this study suggests that shared knowledge practices are directly related to the intermediate measure of organizational performance (namely, productivity), and that the intermediate measure is, in turn, associated with financial performance. Based on this evidence, it was concluded that as long as shared knowledge practices enhance intermediate organizational performance, positive financial performance will result (Lee and Choi, 2003).

In addition to the empirical findings, the findings of the personal interview conducted were reported. Most of the interviewees maintained that shared knowledge allows their manufacturing company to create, communicate, and apply knowledge of all kind to achieve business objectives. This is corroborated by Kirk Klasson who opines that shared knowledge is ability by which greater value can be created and retained from core competencies of business. Shared knowledge labels business issues and problems particularly of its creation, administration, improvement of work processes and practices, and produces innovative products and services, interviewees in their opinion also said that shared knowledge allows their form to retain, enhance, and manage the relationships with current and new customers, and also with the stakeholders of the organization.

Moreover, interviewees responded that valuable human and knowledge resources will be wasted unless management openly accepts and supports efforts to gather, sort, transform, record and share knowledge. According to Yang (2007), knowledge integration and sharing are the major factors that lead to an excellent competitive advantage. He argued that organizations can switch from a situation where intellectual liabilities are created by loss or inappropriate utilization of knowledge into situation of effective utilization of shared knowledge which creates intellectual assets. Shared knowledge is also used to generate and enhance business, and to create competitive advantage. Due to the rapid changes in a business environment, sustainability of an organization is possible only if the knowledge trademark is utilized (Grant, 1996)

\section{CONCLUSION AND RECOMMENDATIONS}

This study examined effect of shared knowledge on the productivity aspect of performance of the manufacturing firms in Nigeria. It was emphasized that the most significant gap in the literature is the lack of large-scale empirical evidence that shared knowledge and organizational performance in Nigeria. It was established that shared knowledge had a positive contribution on the performance of the manufacturing firms. As shared knowledge increased, the performance of the manufacturing firms increased. This suggests the facts that skills and specialized information available to a group of workers in team increased the ability of the manufacturing firms studied to achieve their organizational objective. So the competence due to information that was part of what the group had in the manufacturing firms studied improved the extent to which the manufacturing firms made them to achieve the good results and attain their goals and objectives. It is also concluded here that the level of knowledge of employee determine the productivity aspect of performance of the manufacturing firms. As workers shared their knowledge, they acquire new skills and knowledge which will enhance their productivity.

Based on the findings of the study, the following recommendations are made:

- The strategic managers of the manufacturing firms studied should as a matter of policy continue to use shared knowledge as a tool for improving productivity aspect of performance in their companies.

- The staff of the manufacturing firms should continue to use shared knowledge in their daily activities to improve their performance.

- Shareholders of the manufacturing companies studied should continue to use shared knowledge so as to enhance their decision making process.

- The economic policy makers should continue to use shared knowledge in their strategic policy making process to turn around the economy.

- The strategic managers of the manufacturing firms studied should continue to adopt the benchmarking process of the contribution of shared knowledge on the efficiency aspect of 
performance to meet the international standard.

\section{REFERENCES}

Ajike, E.O., Akinlabi, B.H., Nanle, M., and Sonubi, A.O. (2015). Effect of conflict management on the performance of financial service organization in Nigeria: An empirical study of Access Bank of Nigeria Plc. International Journal of Economic, Commerce and Management, 3(7): 260-272.

Akinniyi, A.A. (2013). Knowledge management practices and organizational performance of

Alavi, M. \& Leidner, D. E., (2001). Inequity in social exchange. In L. Berkowitz (Ed.),

Argote, L., \& Ingram, P. (2000). Knowledge transfer: A basis for competitive advantage in firms. Organizational Behavior and Human Decision Processes, 82, 150-169.

Armstrong,M (2009) Armstrong Handbook of Human Resources Management Practice. United Kindom Replical press pvt Limited.

Bartol, Kathryn M. \& Srivastava, Abhishek (2002). Encouraging knowledge sharing: the role of organizational reward systems. Journal of Leadership \& Organizational Studies, summer, 9, 64-76.

Beijerse, R (1999) Questions in knowledge Management: Defining and conceptualizing a phonemenon journal of Knowledge Management ps 40-46

Blackler, f(1995) knowledge, knowledge work and experience, organization studies, 16(6) pp 16-36

Cabrera, A., Collins, W. C., and Salgado, J. F. (2006). Determinants of individual engagement in knowledge sharing. International Journal of Human Resource Management, 17(2), 245-264.

Carlson, F. W. (1999) A guide to planning a knowledge management system. Retrieved on February 21, 2013 from http://faculty.ed.umuc.edu

Cohen, W. M., \& Levinthal, D. A. (1990). Absorptive capacity: A new perspective on learning and innovation. Administrative Science Quarterly, 35, 128-153.

Cummings, J. N. (2004). Work groups, structural diversity, and knowledge sharing in a global organization. Management Science, 50(3), 352-364.

Davenport, Thomas H., Long, David W. De \& Beers, Michael C. (1998). Successful knowledge management projects. Sloan Management Review, 39(2), 43-57.

Drucker,p (1988) The coming of the new organization, Harvord Business Review, January-Febuary, pp 45-53

Earl, M. (2001). Knowledge management strategies: toward a taxonomy. Journal of Management Information Systems, 18, 215-233.

Fischer, U. and Stokic, D. (n.d.) Organisational knowledge management in manufacturing enterprises - solutions and open $\quad$ issues. $\quad$ Retrieved $\quad$ on $12 / 10 / 14$ from http://www.knowledgeboard.com//download $/ 204 / \mathrm{km}$ in manufacturing enterprises.pdf.

Hansen, M.T, Nohria, N and Tierney, T(1999) What's your strategy for managing Knowledge? Harvard Business Review March - April, pp 106-16 Information Systems, 20(1): 179-228.

Inkpen, A. C (2000) "Learning through Joint Ventures: A Framework of Knowledge

Kanaan, R. Masa'deh, R and Gharibeh, H. (2013). The impact of knowledge sharing enablers on knowledge sharing capability: An empirical study on Jordanian Telecommunication Firms. European Scientific Journal, 9 (22): 237-258.

Keramati, A and Axadeh, M.A (2007) "Exploring the Effects of Top Management's Commitment on Knowledge Management Success in Academia: A Case Study," Proceedings of World Academy of Science Engineering and Technology, Vol. 21, May

Kim, S. and Lee, H. (2006). "The impact of organizational context and information technology on employee knowledge-sharing capabilities." Public Administration Review, May-June.

Kogut, B., \& Zander U. (1992). Knowledge of the firm, combinative capabilities, and the replication of technology. Organization Science, 3, 383-397.

Kremp, E and Mairesse, J (2003) "Knowledge Management, Innovation and Productivity: A Firm Level Exploration Based on the French CIS 3 Data".

Kuo, T. and Wu, A (2007) "The Determinants of Organisational Innovation and Performance: An Examination of Taiwanese Electronics Industry" AAA 2007 Management Accounting Section (MAS) Meeting, http://ssm.com/abstract.

Lee, H. and Choi, B. (2003) Knowledge management enablers, processes, and organizational performance: an integrative view and empirical examination. Journal of Management

manufacturing industry in Nigeria. A pre-field seminar presentation for the award of Doctoral Degree in the Department of Library, Archival \& Information Studies, Faculty of Education, University of Ibadan, Nigeria.

Mohammed, S. (2006) Antecedents and impacts of knowledge management practices supported by information technology: an empirical study in manufacturing context. Dissertation submitted in partial fulfilment of the requirements for PhD in Manufacturing Management in Engineering at the Graduate School, The University of Toledo. 
Mohrman, S.A., Finegold, D. and Mohrman, A.M. (2003) An empirical model of the organisational model system in new product development firms. Journal of Engineering and Technology Management, 20(1-2): 7-38.

Nonaka, 1 (1991) the knowledge creating company, Harvard Business Review, nov-dec, pp 96-104

Nonaka, land Takeuchi, H(1995) The knowledge creating company, Oxford university press, New York

Nonaka, Ikujiro (1994). A dynamic theory of organizational knowledge creation. Organization Science, 15(1), 1994.

Nwachukwu, C.C (2008) Management Theory and Practice, Onitsha: Africana FEB Publishers Limited.

Okunoye, A. and Karsten, H. (2002) Where the global needs the local: variation in enablers in the knowledge management process. Journal of Global Information Technology Management, 5(3): 12-31.

Peariasamy, T. and Mansor, N.N. (2008). On-the-job knowledge sharing: how to train employees to share job knowledge. Jurnal Kemanusiaan bil. 12, Dis, 1-15.

Pulakos, E. D., Dorsey, D. W., \& Borman, W. C. (2003). Hiring for knowledge-based competition. In S. E. Jackson, M. A. Hitt \& A.S. Denisi (Eds.), Managing knowledge for sustained competitive advantage: Designing strategies for effective human resource management (pp. 155-176). San Francisco: Jossey-Bass. Ryle, G (1949) The concept of mind, Oxford university press, Oxford

Rochart, J.F (1979) “CEs Define Their Own Data Needs," Harvard Business Review, Mar-April.

Roy, M., Parent, R. and Desmarals, L.( 2003).”Knowledge networking: a strategy to improve workplace health and safety knowledge transfer." Electronic Journal of Knowledge Management, Vol. 1 Issue 2.

Ryle, G (1949) The concept of mind, Oxford university press, Oxford

Scarborough, H and carter, c (2000) investigating knowledge Management Review, CIPD, London.

Scarborough, H, Swan, 3 and preston, 3(1999) Knowledge Management. A literature Review, Institute of Personnel and Development, London.

Sethi, R. and Sethi, A. (2009). Can quality-oriented firms develop innovative new products? Journal of Product Innovative Management 26(2): 206-221.

Shiah-Hou, S.G., Joseph Yu, C. and Seetoo, D.(2006). The Effects of Power Expectations on the Intent to Share Knowledge: The Case of Supervisors in the Banking Industry. The Journal of Human Resource and Adult Learning 166-175.

Szulanski, G., Cappetta, R., and Jensen, R. J. (2004). When and how trustworthiness matters: Knowledge transfer and the moderating effect of causal ambiguity. Organization Science, 15, 600-613.

Tan, J (2000) Knowledge Management - just more buzzwords; British journal of Administrative March/April pp $10-11$

Wu, S., Lin, C.S. and Lin, T.C. (2006). "Exploring knowledge sharing in virtual teams: a social exchange theory perspective." Proceedings of the 39th Annual Hawaii International Conference, Kauai, Hawaii. 